\title{
Toxoplasma gondii in livestock in St. Kitts and Nevis, West Indies
}

\author{
Clare M Hamilton ${ }^{1,2}$, Patrick J Kelly ${ }^{2}$, Paul M Bartley ${ }^{1}$, Alison Burrells ${ }^{1}$, Alice Porco ${ }^{2}$, Deidra Metzler ${ }^{2}$, Kirsten Crouch², \\ Jennifer K Ketzis ${ }^{2}$, Elisabeth A Innes ${ }^{1}$ and Frank Katzer ${ }^{1^{*}}$
}

\begin{abstract}
Background: Toxoplasma gondii is a ubiquitous protozoan parasite capable of infecting all warm-blooded animals including livestock. In these animals, the parasite forms cysts in the tissues which may pose a risk to public health if infected meat is consumed undercooked or raw. The aim of this study was to determine the exposure of livestock to T. gondii in St. Kitts and Nevis.
\end{abstract}

Methods: Sera and/or heart tissue and meat juice were collected from pigs $(n=124)$, sheep $(n=116)$ and goats $(n=66)$ at the St. Kitts Abattoir. Sera and meat juice were screened for reactive antibodies to T. gondii using an in-house ELISA. Heart tissue was screened for T. gondii DNA using quantitative PCR and positive samples were genotyped using RFLP.

Results: Antibodies to T. gondii were detected in sera from $48 \%$ of pigs, $26 \%$ of sheep and $34 \%$ of goats tested. Antibodies were also detected in the meat juice from $55 \%$ of pig hearts, $22 \%$ of sheep hearts and $31 \%$ of goat hearts tested. There was a significant positive correlation between serology and meat juice results. T. gondii DNA was detected in heart tissue of $21 \%$ of pigs, $16 \%$ of sheep and $23 \%$ of goats tested. Preliminary PCR-RFLP analysis identified a predominance of the Type III genotype of T. gondii.

Conclusions: These results suggest widespread environmental contamination with $T$. gondii oocysts and that livestock could be a potentially important source of T. gondii infection if their infected meat is consumed (or handled) undercooked.

Keywords: Toxoplasma gondii, Livestock, Abattoir, Caribbean, Seroprevalence, Genotype

\section{Background}

Toxoplasma gondii is a ubiquitous protozoan parasite capable of infecting all warm-blooded animals, including people [1]. Felids are the only known definitive host of the parasite and can shed millions of environmentally resistant oocysts in their faeces following primary infection [2]. In intermediate hosts, the parasites develop into cysts in various tissues and may persist in a viable state for the lifetime of the host. Most infections of herbivorous livestock follow ingestion of infective oocysts contaminating the pasture, feeds or drinking water. Infection of pigs can also occur this way or through the ingestion of rodents or other small mammals harbouring $T$. gondii

\footnotetext{
* Correspondence: Frank.Katzer@moredun.ac.uk

${ }^{1}$ Moredun Research Institute, Pentlands Science Park, Bush Loan, Edinburgh EH26 OPZ, UK

Full list of author information is available at the end of the article
}

cysts in their tissues [3]. Congenital transmission, resulting from a primary infection with $T$. gondii during pregnancy, can occur in most livestock and is a major cause of reproductive failure in sheep and goats worldwide. Although there are occasional abortions and premature births in pigs, most infections are subclinical or result in mild, nonspecific signs. Cattle very rarely exhibit clinical signs [4].

Worldwide seroprevalences of $T$. gondii in livestock vary widely, ranging from $3 \%$ to $96 \%$ in sheep [5], $4 \%$ to $77 \%$ in goats [6], $0.4 \%$ to $96 \%$ in pigs $[7,8]$ and $2 \%$ to $83 \%$ in cattle $[6,9]$, with seropositivity increasing with age [10]. Once infected, livestock may harbour T. gondii tissue cysts for the duration of their lifetime, presenting a potentially significant risk to public health if their meat is consumed raw or undercooked. It is estimated that one third of the human population is infected with $T$. gondii although regional seroprevalences vary widely 
[11]. Humans become infected with $T$. gondii by ingesting tissue cysts from meat, or by ingesting oocysts from contaminated food or water, or directly from the environment. The importance of transmission routes in humans may vary between different ethnic groups and geographical locations; however, consumption of undercooked meat is a significant risk factor and may result in $50 \%$ or more of toxoplasmosis cases [12]. In immune-competent people, toxoplasmosis is usually subclinical or a mild, flulike disease; however, in immune-compromised individuals, there can be severe clinical signs and fatalities [13]. Congenital toxoplasmosis can lead to abortion, neonatal death, neurological signs such as hydrocephalus, or ocular signs such as chorioretinitis [13]. The disease burden of congenital toxoplasmosis, as represented by the disabilityadjusted life years, is the highest among all food-borne pathogens [12].

Variation in disease outcome may be related to inoculum dose, infecting stage, and the genetic diversity of the infecting strain [6]. Previously, T. gondii was thought to comprise 3 predominant clonal lineages (designated Types I, II and III), with little genetic diversity $[14,15]$. Recent reports from Brazil and French Guiana, however, have documented cases of severe toxoplasmosis and ocular disease in immune-competent patients following infection later in life. Disease in these individuals has been linked to genetically distinct strains of T. gondii $[16,17]$.

Although the more limited and distinct geography and biodiversity of the Caribbean islands facilitates epidemiological studies on $T$. gondii, there is little data on infections. Infections appear to be common, however, with seroprevalences of $8 \%$ to $43 \%$ reported in livestock from various islands $[18,19]$. Furthermore, there are high seroprevalences in domestic (85\%) and feral (74\%) cats $[20,21]$ on St. Kitts, and genetic characterization of isolates from some of the feral cats revealed 4 genotypes, including Type II, Type III and two unique genotypes [21]. Genetic characterization of T. gondii isolates from chickens in Grenada revealed a predominance of Type III [19], and a recent study in dogs on the island reported the presence of unique genotypes along with Types II and III [22].

To provide further information on T. gondii in the Caribbean, we performed serology on livestock being slaughtered at the St. Kitts Abattoir and used real time PCR to detect parasite DNA within their tissues.

\section{Methods}

\section{Sampling location and animals}

Saint Kitts and Nevis are a small island federation located in the Eastern Caribbean, $17^{\circ} 20^{\prime}$ North, 62 $45^{\prime}$ West. St. Kitts is $168 \mathrm{~km}^{2}$ with a population of approximately 35000 , and Nevis is $93 \mathrm{~km}^{2}$ with a population of approximately 15000 . St. Kitts Abattoir is located in
Basseterre, the capital of St. Kitts, and processes sheep, goats, pigs and cattle from both islands. The majority of animals are brought to the abattoir by traders who have bought them from farmers on either/both island. As the varying numbers of animals brought to the abattoir each week by traders often came from multiple farms, it was not possible to accurately determine the demographics of the animals. Cattle were excluded from the study as they appear to play little role in the epidemiology of human toxoplasmosis and only small numbers (0-7) were slaughtered each week. Sheep belonging to Ross University School of Veterinary Medicine (RUSVM), St. Kitts, were also used in the study. Demographic data on these animals was also not available as they originated from farms around St. Kitts.

The study was conducted between November 2013 and March 2014. Ethical approval was obtained from the Institutional Animal Care and Use Committee of RUSVM, and permission for collection of samples at St. Kitts abattoir was granted by St. Kitts and Nevis Government and the Chief Veterinary Officer. Permission was also sought from the traders by the abattoir manager.

\section{Antigen preparation for ELISA}

Toxoplasma gondii RH strain tachyzoites were grown in pre-cultured Vero cells (ATCC ${ }^{\bullet}$ CCL-81 $1^{\mathrm{mm}}$ ) in IMDM (supplemented with $2 \%$ FCS, $200 \mathrm{IU}$ penicillin/ml and $200 \mu \mathrm{g} / \mathrm{ml}$ streptomycin) at a ratio of 1:2 (Vero cell: $T$. gondii tachyzoites). When all Vero cells were lysed and free tachyzoites were visible in the medium, it was centrifuged for $10 \mathrm{~min}$ at $675 \times \mathrm{g}$ and the supernatant discarded. After two washes in $50 \mathrm{ml}$ PBS $(675 \times$ g for 10 min) the pellet was resuspended in $25 \mathrm{ml}$ PBS and tachyzoites counted using a Neubauer haemocytometer. After adjusting the final concentration to $10^{9}$ tachyzoites per $\mathrm{ml}$ with antigen extraction buffer $(50 \mathrm{mM}$ sodium phosphate $\mathrm{pH}$ 7.6, $1 \mathrm{mM}$ phenylmethanesulfonylfluoride (PMSF), $2 \mathrm{mM}$ EDTA $\mathrm{pH} 7.5,2 \mu \mathrm{g} / \mathrm{ml}$ pepstatin), saponin $(0.5 \%)$ and octylglucoside $(0.5 \%)$ were added and the suspension was incubated for $16 \mathrm{~h}$ at $4^{\circ} \mathrm{C}$ on a blood tube rotator. Following centrifugation for $30 \mathrm{~min}$ at $50,000 \times \mathrm{g}$ at $4^{\circ} \mathrm{C}$, antigen concentration in the supernatant was measured using a Pierce BCA Protein Assay Kit (ThermoFisher, Northumberland, UK). Aliquots (500 $\mu \mathrm{l})$ of supernatant were stored at $-80^{\circ} \mathrm{C}$ until use.

\section{Sera and meat juice preparation}

Blood samples were collected directly from the hearts of pigs, sheep and goats, following removal after slaughter at St. Kitts Abattoir, using 18G disposable needles into vacuum tubes without anti-coagulant. Further blood samples were collected from the sheep being held at Ross University School of Veterinary Medicine, St. Kitts. All sera were obtained following centrifugation $(2000 \times \mathrm{g}$ 
for $10 \mathrm{~min}$ at $4^{\circ} \mathrm{C}$ ) of clotted blood samples and stored at $-20^{\circ} \mathrm{C}$ until use.

Meat juice (fluids that leaked from heart tissue (Section 2.5.1), following $24 \mathrm{~h}$ storage at $4^{\circ} \mathrm{C}$ ) was centrifuged at $1000 \times \mathrm{g}$ for $2 \mathrm{~min}$ to remove debris and supernatants stored at $-20^{\circ} \mathrm{C}$ until use.

Samples were collected from 124 pigs, 116 sheep and 66 goats (Table 1). A complete set of samples was not always obtained from each animal. In some cases we obtained sera alone as trader permission to remove heart tissue, and hence meat juice, could not be obtained (15 pigs, 5 sheep and 2 goats). In other cases, we obtained only heart tissue and meat juice. This occurred when blood could not be aspirated from hearts damaged when carcasses were split (21 pigs, 11 sheep, and 2 goats). We obtained only sera form the 35 live sheep kept at RUSVM.

\section{Toxoplasma gondii ELISA}

In-house ELISAs were adapted from the methodologies of Buxton et al. [23] for sheep and goat sera, and from Burrells [24] for pig sera. Microwells of Greiner Bio-One 96-well medium binding plates were coated with $100 \mu \mathrm{l} /$ well of solubilised RH antigen (See section 2.2) at a concentration of $3 \mu \mathrm{g} / \mathrm{ml}$ in $0.05 \mathrm{M}$ sodium carbonate buffer (pH 9.6) and incubated at $4^{\circ} \mathrm{C}$ overnight. Following incubation, plates were washed 3 times with PBS ( $\mathrm{pH} 7.2)$ containing 0.05\% Tween-20 (PBST).

Sheep and Goat ELISA: Control sera, test sera and meat juice were diluted 1:500 in 1\% BSA in PBST (BSA/ PBST) and $100 \mu \mathrm{l}$ was added to the appropriate microwells, in duplicate. Plates were incubated for $2 \mathrm{~h}$ at $37^{\circ} \mathrm{C}$, and washed 3 times in PBST. $100 \mu \mathrm{l} \mathrm{HRP-conjugated}$ Protein G (Invitrogen) diluted 1:20,000 in 1\% BSA/PBST was added to each well and plates were incubated for 2 $\mathrm{h}$ at $37^{\circ} \mathrm{C}$. Plates were washed 3 times in PBST, and 100 $\mu \mathrm{l}$ substrate (TMB) was added to each well and incubated for $25 \mathrm{~min}$ at room temperature. The reaction was stopped by the addition of $2 \mathrm{M} \mathrm{H}_{2} \mathrm{SO}_{4}$. The OD of each plate was measured at $450 \mathrm{~nm}$ using a microplate reader. Duplicate samples of positive and negative control serum were included on each plate. Control sera were pooled samples from 5 sheep experimentally infected with $T$. gondii, and 5 negative control sheep from the same experiment [25].

Pig ELISA: Plates were blocked for $1 \mathrm{~h}$ at $37^{\circ} \mathrm{C}$ with $125 \mu \mathrm{l} /$ well $1 \%$ BSA/PBST, and washed 3 times in PBST. Control sera, test sera and meat juice were diluted 1:100

Table 1 Samples used in the study and their source

\begin{tabular}{llll}
\hline Sample description & Pigs & Sheep & Goats \\
\hline Sera, meat juice and heart tissue & 88 & 65 & 62 \\
Sera only & 15 & 40 & 2 \\
Heart tissue and meat juice only & 21 & 11 & 2 \\
\hline
\end{tabular}

in $1 \% \mathrm{BSA} / \mathrm{PBST}$ and $100 \mu \mathrm{l}$ was added to the appropriate microwells, in duplicate. Plates were incubated for 1 $\mathrm{h}$ at $37^{\circ} \mathrm{C}$, and washed 3 times in PBST. $100 \mu \mathrm{l} \mathrm{HRP-}$ conjugated Protein G (Invitrogen) diluted 1:20,000 in 1\% BSA/PBST was added to each well and plates were incubated for $1 \mathrm{~h}$ at $37^{\circ} \mathrm{C}$. Plates were washed 3 times in PBST, and $100 \mu \mathrm{l}$ substrate (TMB) was added to each well and incubated for $25 \mathrm{~min}$ at room temperature. The reaction was stopped by the addition of $2 \mathrm{M} \mathrm{H}_{2} \mathrm{SO}_{4}$ and the OD was measured at $450 \mathrm{~nm}$ using a microplate reader. Duplicate samples of negative and positive control serum were included on each plate. Control sera were pooled samples from 5 pigs experimentally infected with T. gondii, and 5 negative control pigs from the same experiment [24].

For each plate, the cut-off value was calculated as two times the percent positivity of the negative control serum relative to the positive control serum (i.e. $[2 \times$ (average negative control sera OD/average positive control sera OD)] $\times$ average positive control) [26].

\section{Detection of $T$. gondii DNA in livestock Collection of heart tissue}

Heart tissue was collected once the pluck (heart, liver, windpipe and lungs) had been removed from slaughtered pigs, sheep and goats by abattoir staff. Portions of the left and right ventricles (at least $50 \mathrm{~g}$ ) were removed and stored individually in sterile sample pots for transportation to the laboratory at RUSVM. Between each sample, knives were washed in water and wiped dry to minimise cross-contamination.

\section{Pepsin digest and DNA extraction}

All heart tissues were digested with acid-pepsin as described by Dubey [27], with modifications. Briefly, $50 \mathrm{~g}$ tissue per sample (free of connective tissue and fat) was cut into $1-2 \mathrm{~cm}$ pieces and homogenised in a $1 \mathrm{~L}$ glass beaker for $30 \mathrm{sec}$ using a hand-held blender. After 100 $\mathrm{ml}$ saline $(0.9 \%)$ was added to the sample it was homogenised again for $30 \mathrm{sec}$ and transferred to a $500 \mathrm{ml}$ glass bottle. The blender and beaker were rinsed with $100 \mathrm{ml}$ saline and these washings were added to the homogenate along with $250 \mathrm{ml}$ pre-warmed $\left(37^{\circ} \mathrm{C}\right)$ acidpepsin solution. After incubation for $60 \mathrm{~min}$ at $37^{\circ} \mathrm{C}$, with frequent mixing, the homogenate was filtered through two layers of gauze, and the resulting filtrate centrifuged for $10 \mathrm{~min}$ at $1200 \times \mathrm{g}$. The pellet was resuspended in $20 \mathrm{ml}$ PBS and neutralized with $15 \mathrm{ml}$ 1.2\% sodium carbonate before centrifugation for $30 \mathrm{~min}$ at $2000 \times$ g. Two millilitres of the homogenised pellet was taken for DNA extraction using the Wizard ${ }^{\circ}$ genomic DNA purification protocol (Promega Corporation, U.K). Volumes used in the manufacturer's protocol were upscaled to allow for the larger starting material, and the 
final DNA pellet was resuspended in $200 \mu \mathrm{l}$ DNase/ RNase-free water and stored at $-80^{\circ} \mathrm{C}$ prior to PCR analysis. To monitor potential cross-contamination between samples, extraction controls (using DNase/RNase-free water) were included within each batch of DNA extractions and processed identically to homogenised tissue.

\section{Real-time quantitative PCR on 529-bp repeat element}

PCR amplifications were carried out, in triplicate, according to the method developed and described by Opsteegh et al. [28], with slight modifications. Amplifications were performed in 96-well plates using an Applied Biosystems 7500 Fast Real Time PCR System. The $20 \mu \mathrm{l}$ reaction mixture consisted of: $10 \mu \mathrm{l} 2 \mathrm{X}$ TaqMan Fast Universal PCR Mastermix No AmpErase ${ }^{\curvearrowleft}$ UNG (Applied Biosystems), $0.7 \mu \mathrm{M}$ of each primer (see [28] for sequences), $0.1 \mu \mathrm{M}$ Tox-TP1 probe (see [28] for sequence) labelled with 6-FAM (5' end) and black hole quencher (BHQ; 3' end), $0.2 \mu \mathrm{M}$ CIAC probe (see [28] for sequence) labelled with JOE ( $5^{\prime}$ end) and BHQ (3' end), $0.01 \mathrm{fg}$ competitive internal amplification control (CIAC; See [28] for details), and 250 ng template DNA in $5 \mu \mathrm{l}$. The reaction mixture was initially incubated at $95^{\circ} \mathrm{C}$ for $10 \mathrm{~min}$ to activate hot-start DNA polymerase. This was followed by 45 amplification cycles that consisted of a $10 \mathrm{~s}$ denaturation step at $95^{\circ} \mathrm{C}$, an annealing step at $58^{\circ} \mathrm{C}$ for $20 \mathrm{~s}$, and an extension step at $72^{\circ} \mathrm{C}$ for $32 \mathrm{~s}$. Fluorescence was measured at $530 \mathrm{~nm}$ (Tox-TP1) and $560 \mathrm{~nm}$ (CIAC-probe) at the end of each extension step. A T. gondii standard series was included in each run for calculation of the standard curve. Non-template controls (NTC) and extraction controls were included in each run. Samples which came up positive on the qPCR were electrophoresed on a 3\% agarose gel incorporating Biotium GelRed ${ }^{\mathrm{Tx}}$ (Cambridge Bioscience Ltd, U.K) to confirm the size of amplicons.

\section{Genetic characterisation of T. gondii by multiplex nested PCR-RFLP}

All samples that tested positive by qPCR were initially genotyped using PCR-RFLP genetic markers SAG2 (3' and $\left.5^{\prime}\right)$, SAG3, BTUB and GRA6 [29-31], using multiplex nested PCR conditions as previously described [32]. Samples that were positively genotyped at one or more loci were further genotyped using genetic markers SAG1, C22-8, C29-2, L358, PK1 and Apico [29,31]. The multiplex PCR reaction for the latter markers was carried out in a $20 \mu \mathrm{l}$ reaction volume containing $2 \mu \mathrm{l} 10 \mathrm{x}$ custom PCR mix [32], $0.1 \mu \mathrm{M}$ of forward and reverse external primers for each of the markers [29], 0.75 units BioTaq (Bioline), $5.9 \mu \mathrm{l}$ DNase/RNase-free $\mathrm{dH}_{2} \mathrm{O}$ and $2 \mu \mathrm{l}$ DNA. To improve the sensitivity of the technique, each multiplex reaction was carried out in quadruplicate. First round cycling conditions were $4 \mathrm{~min}$ at $95^{\circ} \mathrm{C}$, followed by
25 cycles of $30 \mathrm{sec}$ at $94^{\circ} \mathrm{C}, 1 \mathrm{~min}$ at $53.7^{\circ} \mathrm{C}$, and $2 \mathrm{~min}$ at $72^{\circ} \mathrm{C}$. The nested PCR reaction used separate internal primers for each of the markers [29], and used the first round PCR products diluted 1:1 in $\mathrm{dH}_{2} \mathrm{O}$ instead of DNA. The nested PCR was carried out in a $20 \mu \mathrm{l}$ reaction volume containing $2 \mu \mathrm{l} 10 \mathrm{x}$ custom PCR mix (as above), 0.3 $\mu \mathrm{M}$ of forward and reverse primers for each of the markers (except SAG3 where $0.1 \mu \mathrm{M}$ of forward and reverse primers were used), 0.75 units BioTaq (Bioline), 13.9 $\mu \mathrm{l}$ DNase/RNase-free $\mathrm{dH}_{2} \mathrm{O}$ and $2 \mu \mathrm{l}$ diluted first round PCR product. Second round cycling conditions were 4 min at $95^{\circ} \mathrm{C}$, followed by 40 cycles of $30 \mathrm{sec}$ at $94^{\circ} \mathrm{C}, 1$ min at $60^{\circ} \mathrm{C}$, and $1.5 \mathrm{~min}$ at $72^{\circ} \mathrm{C}$ [32]. Positive controls and NTC were included in each PCR run.

Positive nested PCR products $(3 \mu \mathrm{l})$ were digested with the appropriate restriction enzymes as previously described [29,31]. Fragments were separated on a $3 \%$ Metasieve agarose gel (Flowgen Bioscience Ltd, U.K) incorporating Biotium GelRed ${ }^{\mathrm{Tm}}$, and typing was based on RFLP patterns of control reference strains, B1 (Type I), M4 (Type II) and NED (Type III) [32].

\section{Statistical analysis}

Correlation between serum ELISA ODs and meat juice ELISA ODs was carried out using concordance correlation coefficient. Level of agreement between serology results and qPCR results were investigated using Cohen's kappa coefficient. A $P$ value of $<0.05$ was deemed significant. All statistical analyses were carried out using the statistical software package, SPSS.

\section{Results}

Seroprevalence of $T$. gondii in livestock animals

Antibodies to T. gondii were detected in 48\% (95\% confidence interval (CI): 38-57\%) of pig sera (49/103), $26 \%$ (CI: $18-35 \%)$ of sheep sera (27/105) and 34\% (CI: 24$47 \%)$ of goat sera $(22 / 64)$ tested by ELISA (Figure 1 ). Meat juice was also screened for $T$. gondii antibodies to determine its potential as an alternative test sample to sera. Antibodies were detected in 55\% (CI: 47-65\%) of

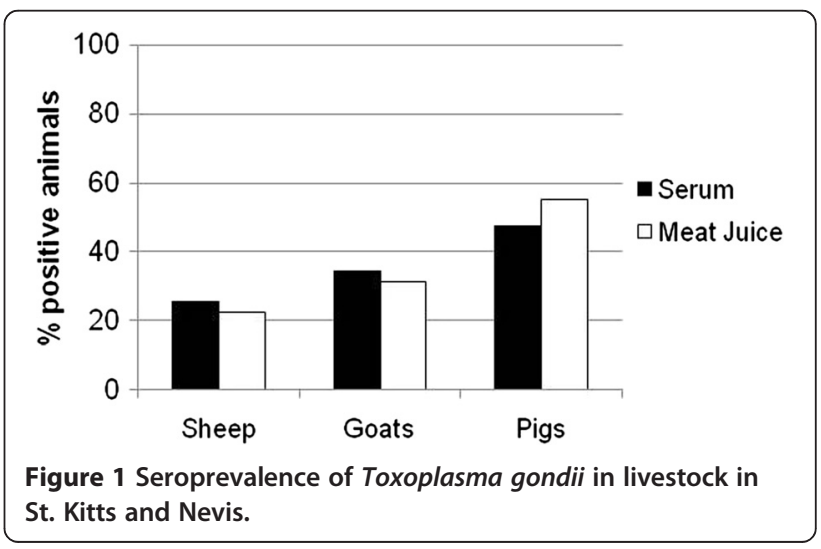


pig meat juice samples (60/109), 22\% (CI: 14-33\%) of sheep meat juice samples (17/76) and 31\% (CI: 21-44\%) of goat meat juice samples (20/64) tested by ELISA (Figure 1). For 215 animals (88 pigs, 65 sheep and 62 goats), there was both a serum ELISA result and a meat juice ELISA result. For these samples, Lin's concordance correlation indicated a significant positive association between serum ELISA ODs and meat juice ELISA ODs (rho_c $=0.899, P<0.001$ ).

\section{Detection of $T$. gondii in tissues of livestock and correlation with serology}

Overall, 20\% (50/249) of the hearts tested were positive for $T$. gondii DNA. Results differed between species, with $21 \%$ (CI: $14-30 \%$ ) of pig hearts testing positive (23/ 109), $16 \%$ (CI: $9-26 \%$ ) of sheep hearts (12/76) and $23 \%$ (CI: $15-35 \%)$ of goat hearts testing positive (15/64) (Table 2).

There was matching serum ELISA results for 215 of the 249 hearts screened for $T$. gondii DNA (Table 3). Similar percentages of pigs $(21 \% ; 18 / 88)$, sheep (15\%; $10 /$ $65)$ and goats $(23 \% ; 14 / 62)$ were positive by both qPCR and serum ELISA whereas a relatively high percentage of pigs $(32 \%$; 28/88) were positive by serum ELISA yet negative by qPCR, compared with only $11 \%$ of sheep (7/ $65)$ and goats $(7 / 62)$. Only one goat $(2 \% ; 1 / 62)$ and two pigs $(2 \% ; 2 / 88)$ were positive by $\mathrm{qPCR}$ and yet negative by serum ELISA. Cohen's kappa coefficient demonstrated there was a moderate $(k=0.5204)$ level of agreement between positive serum ELISA results and positive qPCR results.

Meat juice samples were obtained from all 249 hearts screened for $T$. gondii DNA by qPCR and all were screened for antibodies by ELISA (Table 4). Numbers of animals that were both qPCR and serologically positive were similar to those above where sera was used for ELISA - 20\% of pigs (22/109) and goats (13/64), and $16 \%$ of sheep (12/76). This was also the case for animals that were positive by meat juice ELISA but negative by qPCR - 35\% of pigs (38/109), $11 \%$ of goats $(7 / 64)$ and $7 \%$ of sheep (5/76); and for animals positive by qPCR but negative by meat juice ELISA - 3\% goats $(2 / 64)$ and $1 \%$ pigs (1/109). Again, Cohen's kappa coefficient demonstrated a moderate $(k=0.5030)$ level of agreement between positive meat juice ELISA and positive qPCR results.

Table 2 Detection of Toxoplasma gondii DNA in livestock tissues

\begin{tabular}{llll}
\hline Livestock species & n tested & n positive & \% positive \\
\hline Pigs & 109 & 23 & 21.1 \\
Sheep & 76 & 12 & 15.8 \\
Goats & 64 & 15 & 23.4 \\
\hline
\end{tabular}

Table 3 Correlation between serum ELISA results and qPCR results $(n=215)$

\begin{tabular}{llllll}
\hline $\begin{array}{l}\text { Livestock } \\
\text { species }\end{array}$ & $\mathbf{n}$ & ELISA & qPCR & Total \\
\cline { 3 - 5 } & & & Pos & Neg & \\
\hline Pigs & 88 & Pos & 18 & 28 & 46 \\
& & Neg & 2 & 40 & 42 \\
Sheep & 65 & Pos & 10 & 7 & 17 \\
& & Neg & 0 & 48 & 48 \\
Goats & 62 & Pos & 14 & 7 & 21 \\
& & Neg & 1 & 40 & 41 \\
Total & 215 & & 45 & 170 & 215 \\
\hline
\end{tabular}

\section{Genetic characterisation of $T$. gondii}

Of the 50 animals that tested positive for $T$. gondii by qPCR, 20 (40\%) were successfully amplified with PCRRFLP primers for 1 or more T. gondii markers across 4 loci (Table 5). Of the $20 \mathrm{~T}$. gondii genotypes amplified, 13 originated from pigs, 4 from sheep and 3 from goats. Genotyping revealed that the predominant lineage across all species was Type III (55.0\%), with 2 animals (both pigs) displaying this genotype across all 5 markers (animals 99 and 123) (Table 5). Two animals (both pigs) displayed Type I genotypes - one animal (9) displayed this genotype across all 5 markers, the other (69) was only amplified at a single locus (BTUB). Although no animals displayed the Type II genotype, some had genotypes with apparent re-assorted markers (36 and 37 (both sheep); 97 (pig)). One animal (91; pig) appeared to display a mixed infection with Type II and Type III alleles present at the BTUB locus. Three animals (195, 203, 209; 2 goats and 1 pig, respectively) only amplified at the 5'SAG2 locus where a Type I or Type II genotype could not be deciphered. Attempts to amplify products at additional loci in these animals failed.

\section{Discussion}

Relatively little is known about the epidemiology of Toxoplasma gondii in the Caribbean. Our findings

Table 4 Correlation between meat juice ELISA results and qPCR results $(n=249)$

\begin{tabular}{llllll}
\hline $\begin{array}{l}\text { Livestock } \\
\text { species }\end{array}$ & $\mathbf{n}$ & ELISA & qPCR & & Total \\
\cline { 3 - 5 } & & & Pos & Neg & \\
\hline Pigs & 109 & Pos & 22 & 38 & 60 \\
Sheep & 76 & Neg & 1 & 48 & 49 \\
& & Pos & 12 & 5 & 17 \\
Goats & 64 & Pos & 0 & 59 & 59 \\
& & Neg & 2 & 72 & 20 \\
Total & 249 & & 50 & 199 & 249 \\
\hline
\end{tabular}


Table 5 Genotyping of Toxoplasma gondii DNA isolated from heart tissue from livestock animals in St. Kitts and Nevis

\begin{tabular}{|c|c|c|c|c|c|c|c|}
\hline \multirow[b]{2}{*}{ Reference/Sample } & \multirow[b]{2}{*}{ Species } & \multicolumn{5}{|c|}{ PCR-RFLP marker } & \multirow[b]{2}{*}{ Genotype } \\
\hline & & 5'SAG2 & 3'SAG2 & SAG3 & BTUB & GRA6 & \\
\hline B1 - Type I & & | or || & | or ||| & I & । & I & I \\
\hline M4 - Type II & & | or || & $\|$ & $\|$ & $\|$ & $\|$ & $\|$ \\
\hline NED - Type III & & III & | or ||| & III & III & III & III \\
\hline 6 & Pig & $\mathrm{Na}$ & $\mathrm{Na}$ & III & $\mathrm{Na}$ & $\mathrm{Na}$ & \|\|$^{a}$ \\
\hline 9 & Pig & | or || & | or ||| & I & I & I & I \\
\hline 10 & Pig & $\mathrm{Na}$ & $\mathrm{Na}$ & III & III & III & III \\
\hline 23 & Pig & III & | or III & III & $\mathrm{Na}$ & III & III \\
\hline 29 & Pig & III & $\mathrm{Na}$ & $\mathrm{Na}$ & $\mathrm{Na}$ & $\mathrm{Na}$ & $\| I^{b}$ \\
\hline 36 & Sheep & | or || & $\|$ & $\|$ & $\mathrm{Na}$ & 1 & Re-assort. I and II \\
\hline 37 & Sheep & $\mathrm{Na}$ & $\mathrm{Na}$ & $\|$ & $\mathrm{Na}$ & I & Re-assort. I and $\|^{d}$ \\
\hline 69 & Pig & $\mathrm{Na}$ & $\mathrm{Na}$ & $\mathrm{Na}$ & । & $\mathrm{Na}$ & $1^{c}$ \\
\hline 72 & Pig & III & | or ||| & III & $\mathrm{Na}$ & $\mathrm{Na}$ & III \\
\hline 83 & Sheep & III & $\mathrm{Na}$ & $\mathrm{Na}$ & $\mathrm{Na}$ & $\mathrm{Na}$ & $\| I^{\mathrm{b}}$ \\
\hline 91 & Pig & | or || & $\|$ & III & II and III & $\|$ & Mixed II and III \\
\hline 97 & Pig & | or || & $\|$ & III & $\mathrm{Na}$ & $\mathrm{Na}$ & Re-assort. II and III \\
\hline 98 & Pig & $\mathrm{Na}$ & $\mathrm{Na}$ & III & $\mathrm{Na}$ & III & III \\
\hline 99 & Pig & III & | or ||| & III & III & III & III \\
\hline 123 & Pig & III & | or ||| & III & III & III & III \\
\hline 136 & Goat & III & | or ||| & III & $\mathrm{Na}$ & $\mathrm{Na}$ & III \\
\hline 158 & Sheep & III & | or III & III & $\mathrm{Na}$ & $\mathrm{Na}$ & III \\
\hline 195 & Goat & | or || & $\mathrm{Na}$ & $\mathrm{Na}$ & $\mathrm{Na}$ & $\mathrm{Na}$ & I or $\|^{b}$ \\
\hline 203 & Goat & | or || & $\mathrm{Na}$ & $\mathrm{Na}$ & $\mathrm{Na}$ & $\mathrm{Na}$ & I or $\|^{\mathrm{b}}$ \\
\hline 249 & Pig & | or || & $\mathrm{Na}$ & $\mathrm{Na}$ & $\mathrm{Na}$ & $\mathrm{Na}$ & I or $\|^{\mathrm{b}}$ \\
\hline
\end{tabular}

$\mathrm{Na}=$ no amplification.

Based on a single allele at the SAG3 locus.

based on a single allele at the 5'SAG2 locus.

'Based on a single allele at the GRA6 locus.

${ }^{\mathrm{d}}$ Possible re-assorted markers.

demonstrate that pigs, sheep and goats on St. Kitts and Nevis are exposed to $T$. gondii in their environment. Previous studies on livestock have reported seroprevalences of between $44 \%$ to $89 \%$ in sheep [33], $42 \%$ to $80 \%$ in goats [33] and $6 \%$ to $23 \%$ in pigs $[18,34]$. The seroprevalence rates in sheep and goats in the current study are lower than that previously reported on St. Kitts and Nevis [33]; however, the ages of animals in either study was not known and could be an influencing factor. Seroprevalence is known to increase with age [10] so it is possible the animals in the present study were younger than those sampled previously, leading to a lower seroprevalence. This may be likely given that the animals in the current study were sampled at abattoir and therefore processed for meat production, which normally occurs at a younger age. Worldwide seroprevalence in sheep and goats varies widely and is highly dependent on age of animal and the method of detection used; however, similar prevalences to those in this study have been reported in sheep and goats in South America [35,36], Central America [37], North America [38,39] and Europe $[40,41]$. Previous studies on St. Kitts demonstrated that domestic [20] and feral [21] cats on the island have some of the highest $T$. gondii seroprevalences ever reported, suggesting widespread contamination of the island with oocysts. Sporulated oocysts of $T$. gondii are very resistant to environmental conditions and can remain infective in moist soil or sand for up to 18 months [42] and in water for over a year [43]. They can then be a source of infection for ruminants if they contaminate vegetation in grazing areas or water supplies.

The higher seroprevalence rate in pigs in the present study may be a result of the wider range of transmission routes available to omnivores. Most pigs on St. Kitts and Nevis are reared outdoors where they are more likely to encounter oocysts shed by free-roaming cats and possibly also bodies of dead rodents and other small mammals harbouring $T$. gondii cysts in their tissues. Non-confinement 
housing is known to be a significant risk factor for $T$. gondii transmission [44,45] with seroprevalence rates in pigs in Europe declining over the years with the introduction of more intensive, indoor management systems [7]. The seroprevalence reported in the current study is similar to studies in South $[46,47]$, Central [48] and North America [49], and Europe [50] where outdoor management systems were reported. In each species we studied, the serum ELISA and meat juice ELISA results correlated significantly. This is consistent with previous studies [51-53] and provides further evidence that meat juice samples can be used in seroprevalence studies where serum or plasma samples cannot be collected.

Detection of T. gondii DNA in tissue samples has been shown to be less sensitive than ELISA at detecting infection; however, in most studies, small samples of tissue were used for DNA extraction $(0.2-1 \mathrm{~g})$ [54,55]. We demonstrated a moderate correlation $(k=0.5204)$ between molecular and serological detection of infection but used far larger amounts of tissue ( $50 \mathrm{~g}$ ) for DNA extraction. Since as few as one tissue cyst may be present in 50-100 g tissue [56], our method appears more likely to detect these low levels of infection.

Although our method appears more sensitive, 42 and 50 animals were positive by serum and meat juice ELISA, respectively, yet negative by qPCR. This discrepancy may have been due to the limited amount of sample processed. Although $50 \mathrm{~g}$ of tissue is significantly larger than the standard $<1 \mathrm{~g}$ of tissue normally sampled for DNA extraction from meat, in most cases it did not constitute the whole heart so perhaps tissue cysts were missed during sampling. This is particularly true for the pigs, which may explain why a larger proportion of these animals were positive by ELISA but negative by qPCR. Choice of sample organ may also influence results. The brain is the most common site for T. gondii tissue cysts; however, collection of this organ was not a feasible option at the abattoir so the heart was chosen as this is also a commonly affected organ [57]. It was noted that 3 animals were positive by qPCR but negative by both serum and meat juice ELISAs. This may be because the animals were in the early stages of infection and although there was parasitemia, they had not yet seroconverted. Alternatively, these animals may have been harbouring a chronic infection and their antibody levels had waned [58].

Virtually all edible portions of an animal can harbour viable $T$. gondii tissue cysts [44] and although we did not test skeletal muscle for $T$. gondii, the high number of qPCR-positive animals in this study, and the fact that serologically positive animals can harbour tissue cysts for their lifetime, would suggest that people on St. Kitts and Nevis are at risk of infection by handling or consuming local sheep, goat or pig meat. Consumption of undercooked meat is a significant risk factor for infection [13], although the relative risk differs with cultural habits and geographical location. For example, $84 \%$ of pregnant women in Paris were found to have antibodies to $T$. gondii [44] which may be related to the propensity for French people to consume undercooked meat, particularly lamb [53]. Unfortunately, there is no data on the exposure of people on St. Kitts to T. gondii. In the Caribbean, meat is traditionally cooked very well and the risk of transmission by ingestion of viable tissue cysts is most likely low, since temperatures of over $67^{\circ} \mathrm{C}$ for 10 min will kill tissue cysts [59]. Infections are probably more likely to occur as a result of handling infected meat without subsequent hand washing and by ingesting oocysts on soiled hands or vegetables, or in contaminated water.

Genotyping of qPCR-positive DNA samples in the present study revealed a predominant Type III lineage, which is similar to previous data from the Caribbean. A study on feral cats on St. Kitts reported the presence of Type III genotypes as well as Type II and 2 unique genotypes [21]. Isolation and characterisation of $T$. gondii from free-roaming chickens in Grenada revealed that 29 out of 35 isolates were Type III, one was Type II and four were Type I [19]. In a subsequent study in Grenada, 1 out of $4 T$. gondii isolates from mongooses was Type III and 3 were described as atypical genotypes [60]. In North America and Europe, Type II is the predominant lineage associated with opportunistic infections and congenital infections in humans [61,62], as well as infections in animals [32,63,64]. However, in South America, in particular Brazil, studies in freeroaming chickens have demonstrated that Type II is rare or absent and Type I, Type III and atypical genotypes dominate [65-67]. It is of note that atypical strains have been associated with severe and fatal toxoplasmosis in immune-competent patients in French Guiana [68] and Suriname [69].

Although we genotyped only a limited number of samples, we were able to demonstrate the presence of Type I genotypes in animals destined for the food chain. The Type I genotype is typically virulent in mice [70] and has been associated with reactivation of the parasite in immune-compromised individuals [71]. We also demonstrated possible re-assorted genotypes and mixed infections with alleles of Type II and Type I (10\%) and alleles of Type II and Type III (10\%). A previous study on feral cats in St. Kitts reported the presence of mixed infections (Type II and Type III alleles present across different loci) amongst 5 of 7 cats [21] demonstrating the possibility of infection with more than one genotype on the island. To confirm mixed infections in the current study, PCR products would have to be cloned and sequenced at different loci. 


\section{Conclusions}

In summary, the results of this study suggest widespread environmental contamination in St. Kitts and Nevis with T. gondii oocysts, and that livestock could be a potentially important source of $T$. gondii infection if their infected meat is consumed or handled undercooked. Although only a limited number of samples were genotyped, we demonstrated the presence of Type I genotypes in meat destined for human consumption which may have public health implications since Type I genotypes (or recombinants of Types I and III) have been suggested to be more likely to result in clinical toxoplasmosis [72]. Further studies into the genetic variation of T. gondii on St. Kitts are currently underway in our laboratory, and studies to determine the status of human infection in the region are warranted.

\section{Competing interests}

The authors declare that they have no competing interests.

\section{Authors' contributions}

$\mathrm{CMH}$ collected all heart and blood samples from the abattoir, performed tissue digestion, DNA extraction and genotyping, and also drafted the manuscript. PJK participated in the design of the study and sample collection at abattoir, sought ethical approval for the study, and revised the manuscript. PB helped culture T. gondii tachyzoites and prepare antigen for ELISA. AB helped genotype abattoir samples. AP, DM and KC all participated in sample collection at the abattoir and processing in the laboratory. JKK provided extra blood samples from sheep held on RUSVM campus, helped seek approval for the study from the Department of Agriculture (St. Kitts), and reviewed the manuscript. EAl and FK participated in study design, provided control sera for ELISAs, advised on genotyping experiments and revised the manuscript. All authors read and approved the final manuscript.

\section{Acknowledgments}

The authors would like to thank Dr. Michel Vandenplas and Mrs. Trellor Fraites for help establishing the study; Mr Berry and the staff at St. Kitts Abattoir for co-operating with the study; St. Kitts and Nevis Government and the Chief Veterinary Officer for approving sample collection at the abattoir; the animal traders of St. Kitts and Nevis for allowing us to sample their animals; and Dr. Fortune Sithole for performing the statistical analysis. This work was funded by Ross University School of Veterinary Medicine, the Moredun Research Institute and the Scottish Government (Rural and Environment Science and Analytical Services Division).

\section{Author details}

${ }^{1}$ Moredun Research Institute, Pentlands Science Park, Bush Loan, Edinburgh EH26 OPZ, UK. ${ }^{2}$ Ross University School of Veterinary Medicine, PO Box 334, Basseterre, St. Kitts, West Indies.

Received: 27 January 2015 Accepted: 3 March 2015

Published online: 18 March 2015

\section{References}

1. Dubey JP. The history of Toxoplasma gondii-the first 100 years. J Eukaryot Microbiol. 2008;55:467-75.

2. Hutchison WM, Dunachie JF, Siim JC, Work K. Life cycle of Toxoplasma gondii. Br Med J. 1969:4:806.

3. Kijlstra A, Meerburg B, Cornelissen J, De Craeye S, Vereijken P, Jongert E. The role of rodents and shrews in the transmission of Toxoplasma gondii to pigs. Vet Parasitol. 2008;156:183-90.

4. Hill DE, Dubey JP. Toxoplasma gondii prevalence in farm animals in the United States. Int J Parasitol. 2013;43:107-13.

5. Dubey JP. Toxoplasmosis in sheep-the last 20 years. Vet Parasitol. 2009;163:1-14.
6. Scientific Opinion of the Panel on Biological Hazards on a Request from EFSA on Surveillance and monitoring of Toxoplasma in humans, food and animals. EFSA J 2007, 583:1-64.

7. Dubey JP. Toxoplasmosis in pigs-the last 20 years. Vet Parasitol. 2009;164:89-103.

8. Ortega-Pacheco A, Acosta Viana KY, Guzman-Marin E, Segura-Correa JC, Alvarez-Fleites M, Jimenez-Coello M. Prevalence and risk factors of Toxoplasma gondii in fattening pigs farm from Yucatan. Mexico Biomed Res Int. 2013;2013:231497.

9. Garcia-Bocanegra I, Cabezon O, Hernandez E, Martinez-Cruz MS, MartinezMoreno A, Martinez-Moreno J. Toxoplasma gondii in ruminant species (cattle, sheep, and goats) from southern Spain. J Parasitol. 2013;99:438-40.

10. Katzer F, Brulisauer F, Collantes-Fernandez E, Bartley PM, Burrells A, Gunn G, et al. Increased Toxoplasma gondii positivity relative to age in 125 Scottish sheep flocks; evidence of frequent acquired infection. Vet Res. 2011;42:121.

11. Pappas G, Roussos N, Falagas ME. Toxoplasmosis snapshots: global status of Toxoplasma gondii seroprevalence and implications for pregnancy and congenital toxoplasmosis. Int J Parasitol. 2009;39:1385-94.

12. Torgerson PR, de Silva NR, Fevre EM, Kasuga F, Rokni MB, Zhou XN, et al. The global burden of foodborne parasitic diseases: an update. Trends Parasitol. 2014;30:20-6.

13. Tenter AM, Heckeroth AR, Weiss LM. Toxoplasma gondii: from animals to humans. Int J Parasitol. 2000;30:1217-58

14. Howe DK, Sibley LD. Toxoplasma gondii comprises three clonal lineages: correlation of parasite genotype with human disease. J Infect Dis. 1995; 172:1561-6.

15. Ajzenberg D, Banuls AL, Tibayrenc M, Darde ML. Microsatellite analysis of Toxoplasma gondii shows considerable polymorphism structured into two main clonal groups. Int J Parasitol. 2002:32:27-38.

16. Ferreira IM, Vidal JE, de Mattos CC, de Mattos LC, Qu D, Su C, et al. Toxoplasma gondii isolates: multilocus RFLP-PCR genotyping from human patients in Sao Paulo State, Brazil identified distinct genotypes. Exp Parasitol. 2011;129:190-5.

17. Carme B, Demar M, Ajzenberg D, Darde ML. Severe acquired toxoplasmosis caused by wild cycle of Toxoplasma gondii, French Guiana. Emerg Infect Dis. 2009:15:656-8.

18. Chikweto A, Kumthekar S, Tiwari K, Nyack B, Deokar MS, Stratton G, et al. Seroprevalence of Toxoplasma gondii in pigs, sheep, goats, and cattle from Grenada and Carriacou, West Indies. J Parasitol. 2011;97:950-1.

19. Dubey JR, Bhaiyat MI, de Allie C, Macpherson CN, Sharma RN, Sreekumar C, et al. Isolation, tissue distribution, and molecular characterization of Toxoplasma gondii from chickens in Grenada, West Indies. J Parasitol. 2005:91:557-60.

20. Moura L, Kelly P, Krecek RC, Dubey JP. Seroprevalence of Toxoplasma gondii in cats from St. Kitts, West Indies. J Parasitol. 2007;93:952-3.

21. Dubey JP, Moura L, Majumdar D, Sundar N, Velmurugan GV, Kwok OC, et al. Isolation and characterization of viable Toxoplasma gondii isolates revealed possible high frequency of mixed infection in feral cats (Felis domesticus) from St Kitts, West Indies. Parasitology. 2009;136:589-94.

22. Dubey JP, Tiwari K, Chikweto A, Deallie C, Sharma R, Thomas D, et al. Isolation and RFLP genotyping of Toxoplasma gondii from the domestic dogs (Canis familiaris) from Grenada, West Indies revealed high genetic variability. Vet Parasitol. 2013;197:623-6.

23. Buxton D, Blewett DA, Trees AJ, McColgan C, Finlayson J. Further studies in the use of monensin in the control of experimental ovine toxoplasmosis. J Comp Pathol. 1988:98:225-36.

24. Burrells A. Toxoplasma gondii in animal and human hosts. PhD Thesis, University of Edinburgh, UK, 2014

25. Katzer F, Canton G, Burrells A, Palarea-Albaladejo J, Horton B, Bartley PM, et al. Immunization of lambs with the $\$ 48$ strain of Toxoplasma gondii reduces tissue cyst burden following oral challenge with a complete strain of the parasite. Vet Parasitol. 2014;205:46-56.

26. Semu SM, Peter TF, Mukwedeya D, Barbet AF, Jongejan F, Mahan SM. Antibody responses to MAP $1 B$ and other Cowdria ruminantium antigens are down regulated in cattle challenged with tick-transmitted heartwater. Clin Diagn Lab Immunol. 2001;8:388-96.

27. Dubey JP. Refinement of pepsin digestion method for isolation of Toxoplasma gondii from infected tissues. Vet Parasitol. 1998;74:75-7.

28. Opsteegh M, Langelaar M, Sprong H, den Hartog L, De Craeye S, Bokken G, et al. Direct detection and genotyping of Toxoplasma gondii in meat samples using magnetic capture and PCR. Int J Food Microbiol. 2010;139:193-201. 
29. Prestrud KW, Asbakk K, Mork T, Fuglei E, Tryland M, Su C. Direct highresolution genotyping of Toxoplasma gondii in arctic foxes (Vulpes lagopus) in the remote arctic Svalbard archipelago reveals widespread clonal Type II lineage. Vet Parasitol. 2008;158:121-8.

30. Dubey JP, Patitucci AN, Su C, Sundar N, Kwok OC, Shen SK. Characterization of Toxoplasma gondii isolates in free-range chickens from Chile, South America. Vet Parasitol. 2006;140:76-82.

31. Su C, Shwab EK, Zhou P, Zhu XQ, Dubey JP. Moving towards an integrated approach to molecular detection and identification of Toxoplasma gondii. Parasitology. 2010;137:1-11.

32. Burrells A, Bartley PM, Zimmer IA, Roy S, Kitchener AC, Meredith A, et al. Evidence of the three main clonal Toxoplasma gondii lineages from wild mammalian carnivores in the UK. Parasitology. 2013;140:1768-76.

33. Hamilton CM, Katzer F, Innes EA, Kelly PJ. Seroprevalence of Toxoplasma gondii in small ruminants from four Caribbean islands. Parasit Vectors. 2014;7:449-552.

34. Adesiyun AA, Cazabon EP. Seroprevalences of brucellosis, Q-fever and toxoplasmosis in slaughter livestock in Trinidad. Rev Elev Med Vet Pays Trop. 1996:49:28-30.

35. Clementino MM, Souza MF, Andrade Neto VF. Seroprevalence and Toxoplasma gondii-lgG avidity in sheep from Lajes, Brazil. Vet Parasitol. 2007;146:199-203.

36. Ragozo AM, Yai LE, Oliveira LN, Dias RA, Goncalves HC, Azevedo SS, et al. Isolation of Toxoplasma gondii from goats from Brazil. J Parasitol. 2009;95:323-6.

37. Caballero-Ortega H, Palma JM, Garcia-Marquez LJ, Gildo-Cardenas A, Correa D. Frequency and risk factors for toxoplasmosis in ovines of various regions of the State of Colima, Mexico. Parasitology. 2008;135:1385-9.

38. Dubey JP, Sundar N, Hill D, Velmurugan GV, Bandini LA, Kwok OC, et al. High prevalence and abundant atypical genotypes of Toxoplasma gondii isolated from lambs destined for human consumption in the USA. Int J Parasitol. 2008;38:999-1006.

39. Dubey JP, Adams DS. Prevalence of Toxoplasma gondii antibodies in dairy goats from 1982 to 1984. J Am Vet Med Assoc. 1990;196:295-6.

40. Johnston WS. An investigation into toxoplasmosis as a cause of barrenness in ewes. Vet Rec. 1988;122:283-4.

41. Dubey JP. Toxoplasmosis in Goats (Capra hircus). In: Dubey JP, editor. Toxoplasmosis of Animals and Humans. Boca, Florida: CRC Press; 2010. p. 137-44.

42. Frenkel JK, Ruiz A, Chinchilla M. Soil survival of toxoplasma oocysts in Kansas and Costa Rica. Am J Trop Med Hyg. 1975;24:439-43.

43. Dubey JP. Toxoplasma gondii oocyst survival under defined temperatures. J Parasitol. 1998;84:862-5.

44. Hill DE, Dubey JP. Toxoplasmosis. US Geological Survey Circular 13892014

45. Kijlstra A, Eissen OA, Cornelissen J, Munniksma K, Eijck I, Kortbeek T. Toxoplasma gondii infection in animal-friendly pig production systems. Invest Ophthalmol Vis Sci. 2004;45:3165-9.

46. Venturini MC, Bacigalupe D, Venturini L, Rambeaud M, Basso W, Unzaga JM, et al. Seroprevalence of Toxoplasma gondii in sows from slaughterhouses and in pigs from an indoor and an outdoor farm in Argentina. Vet Parasitol. 2004;124:161-5.

47. Cavalcante GT, Aguiar DM, Chiebao D, Dubey JP, Ruiz VL, Dias RA, et al. Seroprevalence of Toxoplasma gondii antibodies in cats and pigs from rural Western Amazon, Brazil. J Parasitol. 2006;92:863-4.

48. Arias ML, Reyes L, Chinchilla M, Linder E. Seroepidemiology of Toxoplasma gondii (Apicomplexa) in meat producing animals in Costa Rica. Rev Biol Trop. 1994;42:15-20.

49. Gamble HR, Brady RC, Dubey JP. Prevalence of Toxoplasma gondii infection in domestic pigs in the New England states. Vet Parasitol. 1999;82:129-36.

50. Edelhofer R. Prevalence of antibodies against Toxoplasma gondii in pigs in Austria-an evaluation of data from 1982 and 1992. Parasitol Res. 1994;80:642-4.

51. Glor SB, Edelhofer R, Grimm F, Deplazes P, Basso W. Evaluation of a commercial ELISA kit for detection of antibodies against Toxoplasma gondii in serum, plasma and meat juice from experimentally and naturally infected sheep. Parasit Vectors. 2013;6:85.

52. Berger-Schoch AE, Bernet D, Doherr MG, Gottstein B, Frey CF. Toxoplasma gondii in Switzerland: a serosurvey based on meat juice analysis of slaughtered pigs, wild boar, sheep and cattle. Zoonoses Public Health. 2011;58:472-8

53. Halos L, Thebault A, Aubert D, Thomas M, Perret C, Geers R, et al. An innovative survey underlining the significant level of contamination by
Toxoplasma gondii of ovine meat consumed in France. Int J Parasitol. 2010;40:193-200.

54. Warnekulasuriya MR, Johnson JD, Holliman RE. Detection of Toxoplasma gondii in cured meats. Int J Food Microbiol. 1998;45:211-5.

55. Hill DE, Chirukandoth S, Dubey JP, Lunney JK, Gamble HR. Comparison of detection methods for Toxoplasma gondii in naturally and experimentally infected swine. Vet Parasitol. 2006;141:9-17.

56. Dubey JP. Toxoplasmosis of Animals and Humans. 2nd ed. Boca Raton: CRC Press; 2010.

57. Dubey JP. Long-term persistence of Toxoplasma gondii in tissues of pigs inoculated with T gondii oocysts and effect of freezing on viability of tissue cysts in pork. Am J Vet Res. 1988;49:910-3.

58. Caballero-Ortega H, Quiroz-Romero H, Olazaran-Jenkins S, Correa D. Frequency of Toxoplasma gondii infection in sheep from a tropical zone of Mexico and temporal analysis of the humoral response changes. Parasitology. 2008;135:897-902.

59. Dubey JP, Kotula AW, Sharar A, Andrews CD, Lindsay DS. Effect of high temperature on infectivity of Toxoplasma gondii tissue cysts in pork. J Parasitol. 1990;76:201-4

60. Choudhary S, Zieger U, Sharma RN, Chikweto A, Tiwari KP, Ferreira LR, et al. Isolation and RFLP genotyping of Toxoplasma gondii from the mongoose (Herpestes auropunctatus) in Grenada, West Indies. J Zoo Wildl Med. 2013;44:1127-30.

61. Ajzenberg D, Cogne N, Paris L, Bessieres MH, Thulliez P, Filisetti D, et al. Genotype of 86 Toxoplasma gondii isolates associated with human congenital toxoplasmosis, and correlation with clinical findings. J Infect Dis. 2002;186:684-9.

62. Ajzenberg D, Yera H, Marty P, Paris L, Dalle F, Menotti J, et al. Genotype of 88 Toxoplasma gondii isolates associated with toxoplasmosis in immunocompromised patients and correlation with clinical findings. J Infect Dis. 2009;199:1155-67.

63. Dubey JP, Hill DE, Sundar N, Velmurugan GV, Bandini LA, Kwok OC, et al. Endemic toxoplasmosis in pigs on a farm in Maryland: isolation and genetic characterization of Toxoplasma gondii. J Parasitol. 2008;94:36-41.

64. Owen MR, Trees AJ. Genotyping of Toxoplasma gondii associated with abortion in sheep. J Parasitol. 1999;85:382-4.

65. Dubey JP, Graham DH, Blackston CR, Lehmann T, Gennari SM, Ragozo AM, et al. Biological and genetic characterisation of Toxoplasma gondii isolates from chickens (Gallus domesticus) from Sao Paulo, Brazil: unexpected findings. Int J Parasitol. 2002;32:99-105.

66. Dubey JP, Gennari SM, Labruna MB, Camargo LM, Vianna MC, Marcet PL, et al. Characterization of Toxoplasma gondii isolates in free-range chickens from Amazon, Brazil. J Parasitol. 2006;92:36-40.

67. Dubey JP, Velmurugan GV, Chockalingam A, Pena HF, de Oliveira LN, Leifer CA, et al. Genetic diversity of Toxoplasma gondii isolates from chickens from Brazil. Vet Parasitol. 2008;157:299-305.

68. Carme B, Bissuel F, Ajzenberg D, Bouyne R, Aznar C, Demar M, et al. Severe acquired toxoplasmosis in immunocompetent adult patients in French Guiana. J Clin Microbiol. 2002:40:4037-44.

69. Demar M, Ajzenberg D, Maubon D, Djossou F, Panchoe D, Punwasi W, et al. Fatal outbreak of human toxoplasmosis along the Maroni River: epidemiological, clinical, and parasitological aspects. Clin Infect Dis. 2007:45:e88-95.

70. Sibley LD, Khan A, Ajioka JW, Rosenthal BM. Genetic diversity of Toxoplasma gondii in animals and humans. Phil Trans R Soc B. 2014;364:2749-61.

71. Khan A, Su C, German M, Storch GA, Clifford DB, Sibley LD. Genotyping of Toxoplasma gondii strains from immunocompromised patients reveals high prevalence of type I strains. J Clin Microbiol. 2005;43:5881-7.

72. Khan A, Jordan C, Muccioli C, Vallochi AL, Rizzo LV, Belfort Jr R, et al. Genetic divergence of Toxoplasma gondii strains associated with ocular toxoplasmosis, Brazil. Emerg Infect Dis. 2006;12:942-9. 